HEAD AND NECK

\title{
Electrochemotherapy: a well-accepted palliative treatment by patients with head and neck tumours
}

\section{Elettrochemioterapia: trattamento palliativo ben accettato da pazienti con tumori della regione testa e collo}

\author{
B. PICHI ${ }^{1}$, R. PELLINI ${ }^{1}$, A. DE VIRGILIO2*, G. SPRIANO ${ }^{1}$ \\ ${ }^{1}$ Department of Otolaryngology-Head and Neck Surgery, Regina Elena National Cancer Institute, Rome, Italy; \\ 2 Department of Organs of Sense, Ear, Nose, and Throat Section, University of Rome "La Sapienza," Rome, Italy \\ "Present address: Otolaryngology Unit, Humanitas Clinical and Research Center, Rozzano (MI), Italy
}

\section{SUMMARY}

Electrochemotherapy (ECT) is a well established treatment strategy for skin tumuors. The aim of this study was to evaluate the feasibility and efficacy of electrochemotherapy in the palliative setting in patients with head and neck malignancies, in terms of improvement of quality of life and in control of pain and bleeding. Twenty-four patients with a loco-regional M0/M1 relapse not suitable for cure with radical intent by surgery or radiotherapy (RT) and not suitable for systemic therapy and/or already treated with it, were admitted to ECT protocol treatment. Clinical features, treatment response, and adverse effects were evaluated. An overall response of $100 \%$ was observed. Overall survival probability at 24 months was $46.5 \%$ (median OS: 9 months). The multiple application of ECT was associated with improved survival $(\mathrm{p}=0.02)$. Pain, need for medical assistance or dressing and bleeding events was significantly reduced at 1 month after ECT $(p<0.001)$. ECT is effective as palliative treatment of non-resectable head and neck malignancies. Its main advantages are improved quality of life, local tumour control and limited side effects.

KEY WORDS: Electrochemotherapy • Electroporation $\bullet$ Head and neck cancer $\bullet$ Palliation $\bullet$ Supportive care

\section{RIASSUNTO}

L'elettrochemioterapia (ECT) è un trattamento palliativo ben noto dei tumori della cute. Lo scopo di questo studio è quello di valutare la fattibilità e l'efficacia dell'ECT in termini di miglioramento della qualità di vita intesa come riduzione del dolore e del sanguinamento. Ventiquattro pazienti con recidiva loco regionale e con $+/$ - metastasi a distanza non suscettibili di trattamenti sistemici con intenti curativi né chirurgici, né radioterapici né chemioterapici sono stati sottoposti ad elettrochemioterapia in accordo alle line guida ESOPE. I pazienti sono stati seguiti per le caratteristiche cliniche, la valutazione della risposta al trattamento, e la comparsa di eventi avversi. È stata osservata una risposta globale del 100\%. La sopravvivenza globale a 24 mesi è stata del 46,5\% (mediana 9 mesi) Un incremento della sopravvivenza è stato associato a trattamenti multipli di ECT $(p=0,02)$. Si è osservato inoltre ad 1 mese dal trattamento con ECT una riduzione del dolore, della necessità di assistenza medica e di medicazione e del sanguinamento locale statisticamente significativo ( $p<0,001)$. L'ECT si è rivelata un trattamento efficace nell'ambito della palliazione dei tumori ricorrenti/metastatici della testa-collo. I maggiori vantaggi sono il miglioramento della qualità di vita, il controllo loco-regionale con limitata tossicità ed effetti collaterali.

PAROLE CHIAVE: Elettrochemioterapia $\bullet$ Elettroporazione $\bullet$ Tumori testa-collo $\bullet$ Palliazione $\bullet$ Terapia di supporto

Acta Otorhinolaryngol Ital 2018;38:181-187

\section{Introduction}

Worldwide, carcinomas of the head and neck (HNC) account for more than $5 \%$ of all malignancies, which are squamous cell carcinomas in $90 \%$ of cases ${ }^{1}$. Despite multimodal treatment, $50-60 \%$ of patients with stage III or IV disease relapse locoregionally. Of these, most are not suitable for salvage treatment and are eventually candidates for palliation ${ }^{2}$.
In case of unresectable recurrent or persistent disease, Head and Neck 2015 NCCN guidelines recommend re-irradiation +/- systemic therapy, systemic therapy, clinical trial, or best supportive care ${ }^{3}$. These treatment options should be evaluated considering the patient's performance status (PS) and life expectancy.

Electrochemotherapy (ECT) is a well established treatment for cutaneous tumours consisting in the combination of elec- 
troporation and chemotherapy ${ }^{6}$. Electroporation has been studied for approximately 20 years as a means of facilitating the transport of normally non-permeant molecules into cells. By applying an electric field to the cells, the membrane become permeable, allowing chemotherapeutic agents such as bleomycin to enter the cell ${ }^{7}$, increasing its toxicity 89 .

There are four different possible clinical applications of ECT: palliative treatment in case of advanced stage of disease; neoadjuvant role in the form of cytoreductive therapy; organ and function sparing treatment in patients in which conventional therapies cannot be performed; treatment of highly vascularised nodules ${ }^{10}$. The interest for ECT in treatment of the tumours in the H\&N area has increased because specific clinical problems may arise due to failure or expected disfigurement of standard treatments. Many clinical reports described results of electrochemotherapy in treatment of H\&N tumours ${ }^{11-14}$.

The aim of this prospective study was to evaluate the feasibility and efficacy of ECT in the palliative setting in patients with recurrent inoperable head and neck malignancies not suitable for standard palliation by systemic chemotherapy.

\section{Materials and methods}

From April 2012 to April 2015 a total of 24 patients, observed at the Department of Otolaryngology Head and Neck Surgery of the National Cancer Institute Regina Elena, Rome, Italy (21 males, 3 females, age 37-88 years; mean: 69.9 years; median 70 years), with recurrent inoperable head and neck malignancies were submitted to ECT treatment. The clinical trial was approved by the institutional ethics committee and ECT indication was agreed by a multi- disciplinary tumour board for each patient (registration code RS 362/13). Each patient was asked to give written informed consent to participate to the study. All patients had already been treated by multimodal therapy and, at the time of inclusion, presented with a locoregional M0 or M1 relapse not suitable for a cure with radical intent by surgery or RT, and not suitable for systemic therapy and/or already treated with it. Patient demographics and staging characteristics are shown in Table I. The histological characteristics of tumour were assessed. Twenty patients (84\%) were affected by squamous cell carcinoma (SCC), 1 skin melanoma (4\%), 1 synovial sarcoma (4\%), 1 adenocarcinoma (4\%) and 1 mucoepidermoid carcinoma (4\%). In 14 cases (58\%), ECT was delivered at the primary tumour site, in 7 cases $(29 \%)$ at laterocervical lymph nodes and in 3 cases $(13 \%)$ at the primary site and laterocervical lymph nodes (Table I). Only palpable lymph nodes were treated, as revealed by staging. Cervical nodes metastases were all voluminous and palpable. All patients affected by recurrent, metastatic, or primary HNC not suitable for surgery or chemo/radiotherapy on the basis of poor general condition, age, cardiac deficit not related to electrical malfunction, reduced lung performance, comorbidities, high risk of major intrapostoperative complications, risk of anaesthesia, previous treatments, and when the surgery would be too aggressive to be curative, were eligible.

The technical procedure and patient selection were based on the ESOPE guidelines ${ }^{15}{ }^{16}$. Inclusion criteria were: life expectancy longer than 6 months; measurable cutaneous or mucosal tumour lesions. Exclusion criteria included: clinically manifested arrhythmia, interstitial lung fibrosis, epilepsy, active infection, known allergy to bleomycin, kidney failure, previous treatment with bleomycin at the maximum cumulative dosage and different anticancer therapies administered within 2 weeks of the ECT ${ }^{16}{ }^{17}$. Before treatment all patients underwent radiologic evaluation with $\mathrm{CT}$ and/or MRI to define the widest diameter of the lesion. RECIST criteria (Response Evaluation Criteria in Solid Tumors, version 1.1) were applied for evaluation of the results after ECT: complete response (disappearance of all target lesions; any pathological lymph nodes must have reduction in short axis to $<10 \mathrm{~mm}$ ); partial response (at least a 30\% decrease in the sum of diameters of target lesions); progressive disease (at least a 20\% increase in the sum of diameters of target lesions; stable disease (neither sufficient shrinkage to qualify for partial response nor sufficient increase to qualify for progressive disease) ${ }^{18}$.

All lesions were documented by photographs to evaluate aesthetic and functional results after treatment.

\section{ECT protocol}

The procedure was done under mild sedation. When feasible, local anaesthesia consisted of tissue infiltration with $2 \%$ lidocaine.

All patients received an intravenous bolus injection of $15,000 \mathrm{IU} / \mathrm{m}^{2}$ of bleomycin. Eight minutes after the infusion electric pulses were delivered by different types of needle electrodes (hexagonal, or finger) chosen according to the site, volume and shape of the lesions to be treated, and generated by a Cliniporator ${ }^{\mathrm{rM}}$ (IGEA srl, Carpi, Italy). We used hexagonal electrodes in 20 patients $(83 \%)$ and finger electrode in 4 cases (17\%). Needles were inserted into and around the tumour lesions including $1 \mathrm{~cm}$ of safe margin. ECTs were completed within 25 minutes after intravenous administration of bleomycin.

\section{Post-operative evaluation}

Patients were evaluated one month after the treatment and every 3 months until 24 months. Tumour response was 
evaluated according to RECIST criteria ${ }^{13}$ (Table I). Pain was evaluated using a visual analogical scale (VAS) ${ }^{19}$ varying from 0 (no pain) to 10 (extreme pain) before ECT and 1 months after ECT. At each visit, patients were submitted to the same examinations used during pre-operative evaluation (clinical and radiological, photographic). Furthermore, we evaluated hospitalisation time, number of dressings performed by medical staff and bleeding events 1 month before and after ECT. We delivered a single ECT treatment in 14 patients, 2 in 6 patients, 3 in 3 patients and 4 in 1 patient (Table I). In the poration column of Table I, the number of electrodes insertion for each treatment is also indicated. At each follow up visit, in case of evident and symptomatic persistence in terms of pain and/ or bleeding, a new treatment with ECT was planned.

\section{Statistical considerations}

Endpoints included overall survival (OS), disease specific survival (DSS), safety, tolerability, pain control and postoperative care that impact on quality of life. DSS and OS were measured from the time of treatment until death and analysed using the Kaplan-Meier method. A Wilcoxon test was used where appropriate for continuous variables. A multivariate analysis was performed using the Cox proportional hazards model. Statistical significance was considered when $\mathrm{p}<0.05$. The SAS software was used for the statistical analyses (SAS for Windows, version 9.3, SAS Institute Inc., Cary, NC).

\section{Results}

ECT was completed successfully in all patients. All patients were discharged within 24 hours from admission. Post-operative bleeding events never occurred. No major complications were encountered. Post-operative fever was observed in 1 patient (patient 6) and was successfully managed using paracetamol. Post-operative pain was successfully managed at home using oral paracetamol in 23 patients ( 1 gm every 8 hours) for 5 days. Only in 1 patient were opioid medications required for pain control.

The mean follow-up time was 7.6 months (range 2-18 months). Main oncological results are summarised in Table I. OS probability at 12 months was $46.5 \%$, while median OS was 9 months. DSS probability at 12 months was $63 \%$. In 2 of 24 patients a complete response (CR) was observed, while a partial response (PR) was obtained in 22 patients. Twenty of 24 patients were histologically classified as SCC. Repeated treatment was planned at each follow-up visit in case of evident and symptomatic persistence and was necessary in 4 patients as pain and bleeding was still present.
Univariate and multivariate analysis were performed considering as prognostic factors age, gender, ECOG performance status, histology, TNM, application site, number of treatments received per month and use of adjunctive treatment. The only factor significant at univariate and multivariate analysis was the total number of treatments received (HR:0.20, CI:0.05-0.83, $\mathrm{p}=0.02$; HR:0.05, CI:0.00-0.71, $\mathrm{p}=0.02$, respectively; Table II).

Pain evaluation using the VAS scale showed significant pain reduction after ECT. Mean VAS score before treatment was 6.65 vs 2.77 at 1 month after ECT ( $<<0.001$, Table III).

Before treatment, patients referred to our centre a mean of 6.8 times in the last month for the local management (dressings). After treatment, patients referred to our center for a mean of 1.29 times per month. The difference was statistically significant ( $\mathrm{p}<0.001$, Table III). Before ECT, 11 patients (46\%) experienced local bleeding at least once per week. One month after treatment, only 2 patients (2\%) complained of occasional bleeding $(\mathrm{p}<0.001)$.

\section{Discussion}

Even if the majority of patients presenting with an early HNC will remain disease-free after single modality treatment, many patients presenting with an advanced HNC, relapse either locoregionally only, at distant sites only or both. A few patients with a locoregional recurrence can be salvaged by surgery or reirradiation, while most patients with recurrent or metastatic disease only qualify for palliative treatment ${ }^{20}$.

Goals of treatment in these circumstances are mainly symptom control, prevention of new cancer related symptoms, improvement in quality of life, disease stabilisation and possibly prolongation of OS. Often it is necessary to combine local and systemic treatments to achieve the objective of yielding higher cure rates and lower toxicities in head and neck cancers ${ }^{21}$.

In this setting, systemic chemotherapy remains a palliative alternative to best supportive care. Only the cisplatin/5-fluorouracil regimen $(\mathrm{PF})$ and more recently the EXTREME trial (cetuximab + PF regimen, then followed by cetuximab as maintenance therapy) have been demonstrated to improve the OS rate ${ }^{522}$.

According to NCCN guidelines, systemic therapy can be used in association only in case of good PS (0-1) (e.g. EXTREME $^{5}$ ). The limitations of systemic therapy are in its toxicity.

The head and neck is a particularly complex anatomical region due to the presence of critical structures, such as carotid and cranial nerves, compacted in a small space. Thus, 
Table I. Demographics and staging.

\begin{tabular}{|c|c|c|c|c|c|c|c|c|c|c|c|}
\hline Patient & Gender & Age & $\begin{array}{l}\text { ECOG } \\
\text { PS }\end{array}$ & $\begin{array}{l}\text { Histology } \\
\text { and T site }\end{array}$ & TNM (ryc) & $\begin{array}{l}\text { Application } \\
\text { site }\end{array}$ & Response & Porations & Electrode & $\begin{array}{l}\text { Treatment } \\
\text { No. }\end{array}$ & $\begin{array}{l}\text { Adjunctive } \\
\text { treatment }\end{array}$ \\
\hline 1 & M & 52 & 4 & $\begin{array}{l}\text { Larynx } \\
\text { SCC }\end{array}$ & T4aN2cM0 & $\begin{array}{l}\text { Tongue } \\
+ \text { LN }\end{array}$ & $\mathrm{PR}$ & 20 & Hexagonal & 1 & None \\
\hline 2 & M & 79 & 3 & $\begin{array}{c}\text { Ear } \\
\text { melanoma }\end{array}$ & T4bN0M1 & $\begin{array}{c}\text { Retroauricular } \\
\text { skin }\end{array}$ & PR & 40 & Hexagonal & 1 & None \\
\hline 3 & M & 59 & 2 & $\begin{array}{l}\text { Oral cavity } \\
\text { SCC }\end{array}$ & TON2cMO & LN & PR & $\begin{array}{c}31-50- \\
57-90\end{array}$ & Hexagonal & 4 & None \\
\hline 4 & M & 83 & 3 & $\begin{array}{l}\text { Oral cavity } \\
\text { SCC }\end{array}$ & TON2bMO & LN & PR & 14 & Hexagonal & 1 & None \\
\hline 5 & M & 71 & 2 & $\begin{array}{l}\text { Oral cavity } \\
\text { SCC }\end{array}$ & TON2bMO & LN & PR & $20-20$ & Hexagonal & 2 & Cetuximab \\
\hline 6 & M & 75 & 2 & $\begin{array}{l}\text { Preauricular skin } \\
\text { SCC }\end{array}$ & T1N2M1 & $\begin{array}{c}\text { LN } \\
+ \text { preauricular } \\
\text { area }\end{array}$ & PR & $\begin{array}{c}48-59 \\
-50\end{array}$ & Hexagonal & 3 & None \\
\hline 7 & $\mathrm{~F}$ & 83 & 3 & $\begin{array}{l}\text { Oral cavity } \\
\text { SCC }\end{array}$ & T4aNOMO & $\begin{array}{l}\text { Buccal } \\
\text { mucosa }\end{array}$ & PR & 35 & Hexagonal & 1 & None \\
\hline 8 & M & 69 & 2 & $\begin{array}{l}\text { Oral cavity } \\
\text { SCC }\end{array}$ & TON2cMO & LN & PR & 36 & Hexagonal & 1 & None \\
\hline 9 & $\mathrm{~F}$ & 62 & 3 & $\begin{array}{l}\text { Oral cavity } \\
\text { SCC }\end{array}$ & T4aNOMO & $\begin{array}{l}1 / 3 \text { posterior } \\
\text { tongue }\end{array}$ & PR & 13 & Finger & 1 & None \\
\hline 10 & M & 64 & 2 & $\begin{array}{c}\text { Parotid } \\
\text { adenocarcinoma }\end{array}$ & T4aN0M1 & $\begin{array}{l}\text { Preauricular } \\
\text { area }\end{array}$ & PR & 13 & Hexagonal & 1 & None \\
\hline 11 & M & 74 & 3 & $\begin{array}{l}\text { Oral cavity } \\
\text { SCC }\end{array}$ & T4aNOMO & $\begin{array}{l}\text { Chin skin/ } \\
\text { oral cavity }\end{array}$ & PR & 22 & Hexagonal & 1 & None \\
\hline 12 & M & 88 & 4 & $\begin{array}{l}\text { External ear } \\
\text { SCC }\end{array}$ & TOaN3MO & $\begin{array}{l}\text { External } \\
\text { ear }\end{array}$ & PR & 52 & Hexagonal & 1 & None \\
\hline 13 & M & 67 & 2 & $\begin{array}{l}\text { Larynx } \\
\text { SCC }\end{array}$ & T4aNOMO & $\begin{array}{l}\text { Peristomal } \\
\text { recurrence }\end{array}$ & PR & $67-50$ & Hexagonal & 2 & None \\
\hline 14 & M & 69 & 2 & $\begin{array}{l}\text { Oral cavity } \\
\text { SCC }\end{array}$ & T4aN2bM0 & $\begin{array}{l}\text { Oral cavity } \\
\quad+\text { LN }\end{array}$ & $\mathrm{CR}$ & 45 & Finger & 3 & Methotrexate \\
\hline 15 & $F$ & 37 & 1 & $\begin{array}{l}\text { Maxillary sinovial } \\
\text { sarcoma }\end{array}$ & T4aNOM1 & $\begin{array}{l}\text { Maxillary } \\
\text { area }\end{array}$ & PR & $\begin{array}{c}74-55 \\
-10\end{array}$ & Hexagonal & 3 & None \\
\hline 16 & M & 79 & 2 & $\begin{array}{c}\text { Parotid } \\
\text { mucoepidermoid } \\
\text { carcinoma }\end{array}$ & T4aNOMO & $\begin{array}{l}\text { Preauricular } \\
\text { area }\end{array}$ & PR & $65-82$ & Hexagonal & 2 & None \\
\hline 17 & M & 62 & 1 & $\begin{array}{c}\text { Frontal area skin } \\
\text { SCC }\end{array}$ & TON3MO & LN & PR & 53 & Hexagonal & 1 & Extreme \\
\hline 18 & M & 75 & 3 & $\begin{array}{l}\text { Oropharynx } \\
\text { SCC }\end{array}$ & TON2bMO & LN & PR & $30-32$ & Hexagonal & 2 & None \\
\hline 19 & M & 87 & 3 & $\begin{array}{l}\text { Oral cavity } \\
\text { SCC }\end{array}$ & TON3M0 & LN & PR & 21 & Hexagonal & 1 & None \\
\hline 20 & M & 85 & 2 & $\begin{array}{c}\text { Frontal area skin } \\
\text { SCC }\end{array}$ & TON2MO & $\begin{array}{l}\text { Preauricular } \\
\text { area }\end{array}$ & PR & 25 & Hexagonal & 2 & None \\
\hline 21 & M & 62 & 4 & $\begin{array}{l}\text { Chin skin } \\
\text { SCC }\end{array}$ & T4aNOMO & $\begin{array}{l}\text { Chin } \\
\text { skin }\end{array}$ & PR & 96 & Hexagonal & 1 & None \\
\hline 22 & M & 68 & 3 & $\begin{array}{l}\text { Oral cavity } \\
\text { SCC }\end{array}$ & T4aNOMO & $\begin{array}{l}\text { Floor of the } \\
\text { mouth + lips }\end{array}$ & PR & 52 & Finger & 2 & PDT \\
\hline 23 & M & 75 & 3 & $\begin{array}{l}\text { Oral cavity } \\
\text { SCC }\end{array}$ & T4aNOMO & $\begin{array}{l}\text { Oral cavity } \\
\text { mucosa }\end{array}$ & PR & 35 & Finger & 1 & None \\
\hline 24 & M & 53 & 2 & $\begin{array}{l}\text { Oral cavity } \\
\text { SCC }\end{array}$ & T4aNOMO & $\begin{array}{l}\text { Buccal } \\
\text { mucosa }\end{array}$ & $\mathrm{CR}$ & 16 & Hexagonal & 1 & None \\
\hline
\end{tabular}


Table II. Univariate and multivariate analysis of prognostic covariates.

\begin{tabular}{lcccccc} 
Covariate & \multicolumn{3}{c}{ Univariate analysis } & \multicolumn{3}{c}{ Multivariate analysis } \\
Age & HR & $\mathbf{9 5 \% \text { Cl }}$ & $\mathbf{P}$ & HR & $\mathbf{9 5 \%}$ Cl & $\mathbf{P}$ \\
Gender & 0.87 & $0.23-3.28$ & 0.84 & 1.13 & $0.12-10.43$ & 0.90 \\
ECOG PS & 2.16 & $0.42-11.07$ & 0.35 & 0.66 & $0.05-7.95$ & 0.74 \\
Histology & 1.97 & $0.68-5.69$ & 0.20 & 0.24 & $0.02-2.88$ & 0.26 \\
T & 0.50 & $0.06-3.99$ & 0.51 & 0.11 & $0,00-7148.48$ & 0.69 \\
N & 1.02 & $0.73-1.44$ & 0.87 & 1.24 & $0.26-5.89$ & 0.78 \\
M & 0.85 & $0.50-1.45$ & 0.56 & 1,07 & 0.195 .94 & 0.93 \\
Application site & 0.36 & $0.04-2.92$ & 0.34 & 0.63 & $0.00-31421.06$ & 0.93 \\
Treatment No. & 0.55 & $0.18-1.63$ & 0.28 & 0.91 & $0.01-42.14$ & 0.96 \\
Adjunctive treatment & 0.20 & $0.05-0.83$ & 0.02 & 0.05 & $0.00-0.71$ & 0.02 \\
\hline
\end{tabular}

HR: hazard ratio; Cl: confidence interval; PS: performance status; ECOG PS: Eastern Cooperative Oncology Group Performance Status

Table III. Pain and post-treatment management.

\begin{tabular}{lccccc} 
Pain (VAS) & Mean & $\begin{array}{c}\text { Mean } \\
\text { difference }\end{array}$ & SD & $\begin{array}{c}\text { SD } \\
\text { difference }\end{array}$ & $\mathbf{p}$ \\
Time 0 & 6.65 & & 1.16 & & \\
$\begin{array}{l}\text { PostT 1 } \\
\text { month }\end{array}$ & 2.77 & 3.87 & 1.01 & 1.21 & $<0.001$ \\
$\begin{array}{l}\text { Dressings } \\
\text { PreT/month }\end{array}$ & 6.83 & & 1.16 & & \\
PostT/month & 1.29 & 5.54 & 0.55 & 1.17 & $<0.001$ \\
\hline
\end{tabular}

VAS: visual-analogic scale; PreT: pre-treatment; PostT: post treatment; SD: standard deviation.

tumours in head and neck cancer patients are hard to manage ${ }^{1323-29}$. ECT results in a minimal or no functional impact and leads to healing of treated tumour lesions without damage to healthy tissues. For these reasons, ECT is described as an alternative to palliative chemo- or radiotherapy and partial and complete remission rates have been reported in various clinical trials with a low frequency of side effects ${ }^{11} 1330-32$.

Landstrom et al. carried out a phase II trial enrolling patients with early stage (T1-2) oral and base of tongue carcinomas treated with upfront ECT, followed by adjuvant radiation therapy. They observed no recurrence during the entire follow-up period and all patients were alive at 5 years and reported only mild local toxicity ${ }^{33}$.

Bertino et al. in 2016 (actually the largest clinical trial focused on melanoma and non-melanoma skin cancers of the HN area treated with bleomycin electrochemotherapy) demonstrated that better responses are obtained with small lesions $(\leq 3 \mathrm{~cm})$, that primary tumours responded better than secondary (recurrent or metastatic) tumours and that treatment of naïve lesions responded better than pre-treated lesions. Interestingly, for recurrent tumour nodules, previous surgery least affected the outcome compared to (chemo) radiotherapy or multiple treatments ${ }^{34}$.

Di Monta et al., in their retrospective, single-centre study, obtained a overall response after ECT treatment of stage III cSCC of $81 \%$ and CR of $22.7 \%$. ECT is confirmed to display more effectiveness of other therapeutic options in locally advanced cSCC treatment ${ }^{35}$.

In our study, a PR of $83.3 \%$ was observed, while only 2 patients $(1.2 \%)$ presented a CR. Twenty patients $(84 \%)$ were affected by SCC and in this group of patients we observed $10 \% \mathrm{CR}$ and $100 \%$ PR. The low CR observed in comparison of literature data might be due to heterogeneity of our cohort including cutaneous or mucosal tumour localisation and for this reason not perfectly comparable to other studies. In our study, we performed univariate/ multivariate analysis (Table II) considering as prognostic factors age, gender, ECOG performance status, histology, TNM, application site, number of treatments received per month and the use of adjunctive treatment. The only factor that resulted significant was the total number of treatments received. This result could be justified either as an ECT objective survival benefit or as a normal consequence derived from the prolonged survival by some patients. Hopefully, to better investigate the impact of the considered prognostic covariates, a more numerous sample is probably needed.

There are many potential benefits with the use of ECT, the most important of which is its reliability and versatility. The treatment can be performed in virtually every patient independently of the performance status. In fact, it does not require general anaesthesia: we performed all procedures in mild sedation, in an office-based setting, without performing a tracheostomy, even in patients with PS 4. The avoidance of intubation allowed us to better manage patients suffering from microstomia, oral cavity oedema, pain and trismus. 
ECT is very simple to be performed, does not require a long learning curve and is repeatable every 30 days ${ }^{13}$. Probably the best indicator that electrochemotherapy is not too demanding or painful procedure is that among the interviewed patients, 20 of $24(83.3 \%)$ would be willing to accept the treatment again if it indicated. From the first case, we were able to efficaciously complete every treatment without delays or complications. While systemic chemotherapy requires multiple administrations, each ECT treatment is completed in less than 25 minutes because after a single dose of intravenous bleomycin administration, the maximal plasmatic concentration is reached in 8 minutes, is maintained for about 20 minutes and then is gradually reduced. Additionally, any systemic chemotherapy using single or multiple agents imply a certain degree of toxicity that can result in a general impairment (e.g.: anaemia, leukopenia). In our study, we did not experience any major complications or prolonged hospitalisations. This means that ECT can be performed safely even in PS 3-4 without deterioration of quality of life. The main ECT contraindication is represented by lung fibrosis which could be exacerbated by bleomycin. In order to prevent this possibility, all patients performed arterial blood gas analysis the day before the application.

Even in case of partial response, ECT resulted in improvement, especially in terms of pain and bleeding reduction, and need for medical/paramedical care.

ECT by itself is responsible for a certain degree of postoperative pain which was successfully managed using oral paracetamol at home. Only in 1 patient were opioid medications required for pain control. Pain evaluation through the VAS scale resulted in a significant pain reduction after ECT $(p<0.001$, Table III). This resulted in reduction in the administration of pain medications, which are considerably used and often abused by advanced stage HNC patients. A recent study showed that pre-operative pain, previous irradiation, large tumour size and high current values are predictors of post-operative pain. Knowing the risk factors, pain treatment can be better planned in advance ${ }^{36}$.

The utility of ECT was also evident from the significant reduction of medical assistance (dressings, Table III). Patients were able to take care by themselves of the treated area by simple disinfection and dressings. They requested medical assistance only 1.29 times per month. These results depend partially on the significant reduction of bleeding events after ECT. In fact, bleeding was one the main reasons for medical assistance. One month after treatment, only 2 patients (8\%) complained of occasional bleeding.

Reducing the need for the medical support results undoubtedly in an improvement in quality of life both from a psychological point of view (able to self-care) and from a practical point of view (fewer trips to the hospital, costs reduction).
ECT cicatrisation and pain/bleeding reduction is probably due to the 'vascular lock phenomenon'. In fact, blood flow changes occur after the delivery of electric pulses in vivo ${ }^{37}$. In the case of normal tissues, these effects appear as a transient hypoperfusion. In the case of tumour tissues, the vascular lock is much longer than in normal tissues and restoration of the initial blood flow levels may take hours. The mid-term and long-term antivascular effects of ECT could thus result from the killing of tumour endothelial cells, which could prevent the rapid reorganisation of tumour vasculature. Consequently, an almost permanent, extremely hypoxic situation is created after ECT ${ }^{38}$.

A limitation of our study is the relatively small sample size and patient heterogeneity in terms of clinical features and treatment. Our study includes both primary and lymph node recurrences and patients who received concomitant palliative systemic chemotherapy. Our investigation on ECT is still ongoing and we aim to publish more data in the future with more representative samples, stratified by histology, recurrence site and concomitant treatments.

\section{Conclusions}

ECT was shown to be effective in the palliative treatment of non-resectable HNC. The advantages of ECT include improved quality of life and local tumour control, no damage to healthy tissue and limited side effects. We advocate its use in the palliative treatment of $\mathrm{HNC}$, especially in patients with unfavourable PS.

\section{References}

1 Shield KD, Ferlay J, Jemal A, et al. The global incidence of lip, oral cavity, and pharyngeal cancers by subsite in 2012. CA Cancer J Clin 2017;67:51-64.

2 Vokes EE, Weichselbaum RR, Lippman SM. Head and neck cancer. N Engl J Med 1993;328:184-94.

3 Pfister DG, Spencer S, Brizel DM, et al. National Comprehensive Cancer Network. J Natl Compr Canc Netw 2015;13:847-55.

4 Oken MM, Creech RH, Tormey DC, et al. Toxicity and response criteria of the Eastern Cooperative Oncology Group. Am J Clin Oncol 1983;5:649-55.

5 Vermorken JB, Mesia R, Rivera F, et al. Platinum-based chemotherapy plus cetuximab in head and neck cancer. $\mathrm{N}$ Engl J Med 2008;359:1116-27.

6 Mir LM, Orlowski S, Belehradek Jr J, et al. Electrochemotherapy potentiation of antitumour effect of bleomycin by local electric pulses. Eur J Cancer 1991;27:68-72.

7 Heller R, Gilbert R, Jaroszeski MJ. Clinical applications of electrochemotherapy. Adv Drug Deliv Rev 1999;35:119-29.

8 Gehl J, Skovsgaard T, Mir LM. Enhancement of cytotoxicity 
by electropermeabilization: an improved method for screening drugs. Anticancer Drugs 1998;9:319-25.

9 Orlowski S, Belehradek Jr J, Paoletti C, et al. Transient electropermeabilization of cells in culture. Increase of the cytotoxicity of anticancer drugs. Biochem Pharmacol 1988;37:4727-33.

10 Sersa G. The state-of-the-art of electrochemotherapy before the ESOPE study; advantages and clinical uses. EJC Suppl 2006; 4:52-9.

11 Gargiulo M, Papa A, Capasso P, et al. Electrochemotherapy for non-melanoma head and neck cancers. Clinical outcomes in 25 patients. Ann Surg 2012;255:1158-64.

12 Scelsi D, Mevio N, Bertino G, et al. Electrochemotherapy as a new therapeutic strategy in advanced Merkel cell carcinoma of the head and neck region. Radiol Oncol 2013;47: 366-9.

13 Mevio N, Bertino G, Occhini A, et al. Electrochemotherapy for the treatment of recurrent head and neck cancers: preliminary results. Tumori 2012;98:308-13.

14 Campana LG, Mali B, Sersa G, et al. Electrochemotherapy in non melanoma head and neck cancers: a retrospective analysis of the treated cases. Br J Oral Maxillofac Surg 2014;52:957-64.

15 Mir LM, Gehl J, Sersa G, et al. Standard operating procedures of the electrochemotherapy: instructions for the use of bleomycin or cisplatin administered either systemically or locally and electric pulses delivered means of invasive or non invasive electrodes. Eur J Cancer Suppl 2006;4:14-25.

16 Marty M, Sersa G, Garbay JR, et al. Electrochemotherapy an easy, highly effective and safe treatment of cutaneous and subcutaneous metastases: results of ESOPE (European Standard Operating Procedures of Electrochemotherapy) study. Eur J Cancer Suppl 2006;4:3-13.

17 Campana LG, Mocellin S, Basso M, et al. Bleomycin-based electrochemotherapy: clinical outcome from a single institution's experience with 52 patients. Ann Surg Oncol 2009;16:191-9.

18 Eisenhauer EA, Therasse P, Bogaerts J, et al. New response evaluation criteria in solid tumours: revised RECIST guideline (version 1.1). Eur J Cancer 2009;45:228-47.

19 Carlsson AM. Assessment of chronic pain. I. Aspects of the reliability and validity of the visual analogue scale. Pain 1983;16:87-101.

20 Vermorken JB, Specenier P. Optimal treatment for recurrent/metastaticheadandneckcancer.Ann Oncol2010;21(Suppl7):vii252-61.

21 Bernier J, Liu JC. Head and Neck Cancer, Multimodality Management. 2nd Ed. Springer; 2016.

22 Forastiere AA, Metch B, Schuller DE, et al. Randomized comparison of cisplatin plus fluorouracil and carboplatin plus fluorouracil versus methotrexate in advanced squamous-cell carcinoma of the head and neck: a Southwest Oncology Group study. J Clin Oncol 1992;10:1245-51.

23 Burian M, Formanek M, Regele H. Electroporation therapy in head and neck cancer. Acta Otolaryngol 2003;123, 264-8.
24 Landström FJ, Nilsson CO, Crafoord S, et al. Electroporation therapy of skin cancer in the head and neck area. Dermatol Surg 2010;36:1245-50.

25 Landstrom FJ, Nilsson CO, Reizenstein JA, et al. Electroporation therapy for $T 1$ and $T 2$ oral tongue cancer. Acta Otolaryngol 2011;131:660-4.

26 Allegretti JP, Panje WR. Electroporation therapy for head and neck cancer including carotid artery involvement. Laryngoscope 2001;111:52-6.

27 Kyrgias G, Kostopoulou E, Zafiriou E, et al. Hidradenocarcinoma of the temporal area successfully treated with concomitant electrochemotherapy and radiotherapy. Head Neck Oncol 2013;5:14.

28 De Virgilio A, Fusconi M, Greco A, et al. The role of electrochemotherapy in the treatment of metastatic head and neck cancer. Tumori 2013;99:634.

29 Campana LG, Bertino G, Rossi CR, et al. The value of electrochemotherapy in the treatment of peristomal tumors. Eur J Surg Oncol 2014;40:260-2.

30 Sersa G, Stabuc B, Cemazar M, et al. Electrochemotherapy with cisplatin: clinical experience in malignant melanoma patients. Clin Cancer Res 2000;6:863-7.

31 Sersa G, Stabuc B, Cemazar M, et al. Electrochemotherapy with cisplatin: potentiation of local cisplatin antitumour effectiveness by application of electric pulses in cancer patients. Eur J Cancer 1998;34:1213-8.

32 Glass LF, Fenske NA, Jaroszeski M, et al. Bleomycin mediated electrochemotherapy of basal cell carcinoma. J Am Acad Dermatol 1996;34:82-6.

33 Landström FJ, Reizenstein J, Adamsson GB, et al. Long-term follow-up in patients treated with curative electrochemotherapy for cancer in the oral cavity and oropharynx. Acta Otolaryngol 2015;135:1070-8.

33 Bertino G, Sersa G, De Terlizzi F, et al. European Research on Electrochemotherapy in Head and Neck Cancer (EURE$C A)$ project: results of the treatment of skin cancer. Eur $\mathrm{J}$ Cancer 2016;63:41-52.

34 Di Monta G, Caracò C, Simeone E, et al. Electrochemotherapy efficacy evaluation for treatment of locally advanced stage III cutaneous squamous cell carcinoma: a 22-cases retrospective analysis. J Transl Med 2017;15:82.

35 Quaglino P, Matthiessen LW, Curatolo P, et al. Predicting patients at risk for pain associated with electrochemotherapy. Acta Oncol 2015; 54:298-306.

36 Sersa G, Cemazar M, Parkins CS, et al. Tumor blood flow changes induced by application of electric pulses. Eur J Cancer 1999;35:672-7.

37 Cemazar M, Parkins CS, Holder AL, et al. Electroporation of human microvascular endothelial cells: evidence for an anti-vascular mechanism of electrochemotherapy. Br J Cancer 2001;84:565-70.

Received: May 31, 2016 - Accepted: August 3, 2017

Address for correspondence: Barbara Pichi, Department of Otolaryngology-Head and Neck Surgery, Regina Elena National Cancer Institute, via Elio Chianesi 53, 00144 Rome, Italy. Tel. +3906 52666770. Fax +3906 52662015. E-mail: barbara.pichi@ifo.gov.it 